\title{
ANTIBODIES TO SCHISTOSOMA MANSONI IN HUMAN CEREBROSPINAL FLUID
}

\author{
ISIS F. MAGALHÃES-SANTOS, DENISE C. LEMAIRE, ANTONIO S. ANDRADE-FILHO, ARISTIDES C. QUEIROZ, \\ OTÁVIO M. CARVALHO, THEOMIRA M. A. CARMO, ISADORA C. SIQUEIRA, DÉBORA M. ANDRADE, \\ MICHELY F. REGO, ANA PAULA T. GUEDES, AND MITERMAYER G. REIS \\ Centro de Pesquisas Gonçalo Moniz-FIOCRUZ, Oswaldo Cruz Foundation, Salvador, Bahia Brazil; Federal University of Bahia, \\ Salvador, Bahia, Brazil; Escola Bahiana de Medicina e Saúde Pública, Salvador, Bahia Brazil; José Silveira Foundation, \\ Salvador, Bahia Brazil
}

\begin{abstract}
Cerebrospinal fluid (CSF) and serum samples from patients suspected of having neuroschistosomiasis (NS) were evaluated by an enzyme-linked immunosorbent assay. Monoclonal antibodies of various immunoglobulin isotypes (IgM, IgA, IgE, total IgG, IgG1, IgG2, IgG3, and IgG4) were used to detect antibodies against Schistosoma mansoni soluble egg antigen (SEA) and soluble worm adult preparation (SWAP). Of the 83 CSF samples tested, 55\% were reactive to SEA (26\% were reactive only to SEA and $29 \%$ to both SEA and SWAP), $34 \%$ were reactive to SWAP (5\% only to SWAP and $29 \%$ to both SEA and SWAP), and $40 \%$ were not reactive with any antigen. Cases that tested positive for SWAP in CSF and negative in serum were not found. Samples with high specific IgG antibody titers were selected for immunoglobulin isotype profiling. In the CSF samples, the antibodies against SEA and SWAP were mainly $\mathrm{IgM}, \mathrm{IgG1}$, and IgG4, although other immunoglobulins were also detected. Interestingly, nine patients had high levels of IgG1 only in the CSF. These results suggest that there is local synthesis of IgG1, and that this isotype could be an important immunologic marker in the diagnosis of NS.
\end{abstract}

\section{INTRODUCTION}

Schistosomiasis remains a major public health problem, affecting an estimated 200 million people in 74 countries. ${ }^{1}$ The pathology of human schistosomiasis is primarily associated with egg deposition in the liver and intestine (Schistosoma mansoni and S. japonicum) or in the bladder ( $S$. haematobium). On rare occasions, eggs may lodge in almost any other organ of the body. ${ }^{2}$ Ectopic schistosomiasis infection of the central nervous system (CNS) is unusual, and leads to a disease called neuroschistosomiasis (NS). Cerebral lesions are caused primarily by $S$. japonicum, whereas $S$. mansoni and $S$. haematobium usually cause spinal cord lesions. ${ }^{3}$ After the worms have matured and eggs have been laid, there are three mechanisms by which $S$. mansoni or its products may reach the CNS: 1) sparse or massive embolization of ova from the portal mesenteric system to the CNS via the arterial system or through retrograde venous flow, 2) in situ ova deposition following the anomalous migration of adult worms, or 3) deposition of immune complexes in the choroids plexus. ${ }^{4-7}$

A presumptive diagnosis of NS should be based on myelography, magnetic resonance imaging (MRI), clinical and/or laboratory evidence of neurologic lesions, demonstration of schistosome infection (by means of microscopic or immunologic techniques), and the exclusion of other causes of myelitis. $^{8}$ When surgical biopsy or autopsy is not performed, a presumptive diagnosis of NS is based on clinical, laboratory, and epidemiologic evidence.

There have been few investigations of the serology of patients with NS, and most were limited to the search for antibodies in the cerebrospinal fluid (CSF) of patients with myeloradiculopathy. ${ }^{9-12}$ Serologic techniques such as complement fixation, immunofluorescence, Western blotting, and enzyme-linked immunosorbent assay (ELISA) have been used, but none have yet achieved sufficient levels of sensitivity and specificity to justify their consideration as gold standard techniques. ${ }^{2,13-16}$ The main objective of this investigation was to verify the existence of specific antibodies against $S$. mansoni soluble egg antigen (SEA) and soluble worm adult preparation (SWAP) in the CSF of patients suspected of having NS without a history of a disease that could disrupt the blood-brain barrier. In addition, we sought to establish a profile of immunoglobulin isotypes against SEA and SWAP that could characterize this condition.

\section{MATERIALS AND METHODS}

Patients. This study included 83 individuals with a presumptive diagnosis of NS who were admitted to the Neurology Department at the University Hospital of the Federal University of Bahia (Salvador, Brazil) between 1995 and 1997. Patients with evidence of medullary lesions (e.g., bladder and intestinal dysfunctions and/or lower limb weakness) were eligible for inclusion. Those who had other causes of myeloradicular damage confirmed by clinical or laboratory evidence were excluded. The clinical and laboratory characteristics of these patients are shown in Table 1. Two control groups were used: 1) 40 patients with myelitis not associated with schistosomiasis (excluding patients with bacterial meningitis) were enrolled as clinical controls, and 2) 20 patients with a confirmed diagnosis of neurocysticercosis were included to test for ELISA cross-reactivity. All participants gave their informed consent, and the Institutional Ethical Committee approved the project protocol.

The following procedures were performed prior to administration of chemotherapy in all patients: examination of CSF (biochemistry, cytology, Venereal Disease Research Laboratory test, and immunoassays for cysticercosis and toxoplasmosis), chest radiograph, ultrasonography, and immunofluorescence test for schistosomiasis antibodies. In two cases, it was possible to perform an MRI. Serum collection and fecal examination were performed on the same day as lumbar puncture. Patients with a history of infection with human immunodeficiency virus, HTLV-I, and HTLV-II, Guillain-Barré syndrome, Chagas' disease, encephalopathy, bacterial meningitis, or viral meningomyeloradiculitis were excluded. ${ }^{17}$

Samples. The CSF (obtained by lumbar puncture) was collected from 83 patients as part of a routine hospital-based clinical laboratory investigation. In addition, serum samples were obtained from a randomly selected subset of 49 patients that consented to having their blood drawn. All samples were collected before initiation of treatment with corticosteroid or 
TABLE 1

Clinical and laboratory characteristics of patients with suspected neuroschistosomiasis*

\begin{tabular}{ll}
\hline \multicolumn{1}{c}{ Characteristic } & Number (\%) \\
\hline Clinical forms $(\mathrm{n}=83)$ & $68(82)$ \\
Meningomyeloradiculitis & $10(12)$ \\
Myelitis & $3(4)$ \\
Radiculitis & $2(2)$ \\
Pseudotumor & $39(47)$ \\
CSF laboratory data $(\mathrm{n}=83)$ & $80(97)$ \\
Eosinophils $(\geq 1 \%)$ & $83(100)$ \\
Proteins $(>30 \mathrm{mg} / 100 \mathrm{ml})$ & $57(69)$ \\
Glucose $(>2 / 3$ of serum value) & \\
Positive immunofluorescence & $10(15)$ \\
Fecal parasitology (n $=67)$ & $57(85)$ \\
Presence of schistosome eggs & \\
Absence of schistosome eggs &
\end{tabular}

antischistosomal drugs. After collection, aliquots of CSF and serum were immediately stored at $-20^{\circ} \mathrm{C}$. Each antibody cutoff value for this study was established by calculating the mean optical density value plus three times the standard deviation. The CSF cut-off value for total $\mathrm{IgG}(\mathrm{SEA}=0.15$, SWAP $=0.22$ ) was calculated using samples from 30 patients with neuropathies other than NS, and the serum cut-off value for total $\mathrm{IgG}(\mathrm{SEA}=0.25, \mathrm{SWAP}=0.15)$ was determined using sera from 20 healthy donors.

Enzyme-linked immunosorbent assay. The SEA and SWAP antigens were obtained from $S$. mansoni eggs and adult worms, respectively, as described elsewhere. ${ }^{18}$ Polystyrene microtiter plates (Immulon 2; Dynatech, Geneva, Switzerland) were coated with SEA or SWAP (1 mg/well) diluted in $0.05 \mathrm{M}$ carbonate buffer, $\mathrm{pH} 9.6$, and left at $4^{\circ} \mathrm{C}$ overnight. Non-specific attachment sites were blocked with 5\% skimmed milk diluted in $0.15 \mathrm{M}$ phosphate-buffered saline $\mathrm{pH} 7.2$ (PBS) containing $0.3 \%$ of Tween-20 (Sigma, St. Louis, MO) and incubated at room temperature for one hour. Between each step, the plates were rinsed six times with a mixture of PBS and $0.05 \%$ Tween-20. The CSF and serum samples were diluted $1: 100$ and 1:1,000, respectively, with a mixture of PBS and $0.05 \%$ Tween-20, and incubated at $4^{\circ} \mathrm{C}$ overnight. Bound specific IgG was detected using goat anti-human peroxidaseconjugated IgG (Boeringer-Mannhein, Mannheim, Germany) diluted 1:1,000 in PBS-Tween $0.05 \%$. Tetramethylbenzidine and hydrogen peroxide (1:1) (Kirkegaard and Perry Laboratories, Gaithersburg, MD) were used to develop the plates, and absorbance was read at $450 \mathrm{~nm}$.

The same ELISA protocol was followed for isotype characterization. The CSF samples were diluted at 1:20 for all immunoglobulin isotypes except $\mathrm{IgE}$, which was diluted 1:2 to accommodate low total IgE concentrations. The serum samples were diluted 1:1,000 in PBS-Tween (0.05\%). Bound specific antibodies were detected with monoclonal antibodies from mouse anti-human $\operatorname{IgM}, \operatorname{IgA}$, and $\operatorname{IgE}$ peroxidase conjugates and mouse anti-human IgG1, IgG2, IgG3, and IgG4 biotin conjugates (Sigma). For the detection of specific IgG1, IgG2, IgG3, and IgG4 human antibodies, an additional incubation with a streptavidin-peroxidase conjugate (Sigma) was performed prior to the development process.

Statistical analysis. Chi-square and Fisher's exact tests were used to evaluate differences in the number of patient samples that tested positive for antibodies.

\section{RESULTS}

The 83 patients included in this study ranged in age from five to 77 years old $($ median $=36.00) ; 53(63.8 \%)$ were male, $30(36.2 \%)$ were female, and all patients had lived in or visited areas endemic for schistosomiasis with various levels of transmission. The percentage of serum and CSF samples that had high levels of antibodies against SEA and SWAP is shown in Figure 1. IgG antibodies against SEA were detected more frequently than IgG against SWAP in the CSF samples (55\% versus $34 \%$ of the 83 CSF samples; $P=0.00009482$ ), but there was no statistically significant difference between the frequency of antibodies to SEA and SWAP in the serum samples $(P=0.1955782)$. There were no differences in clinical presentation between patients with negative or positive results in CSF or serum.

When the paired samples of CSF and serum $(n=49)$ were analyzed, $28(57 \%)$ of these samples had detectable levels of antibodies against SEA in both CSF and serum. Interestingly, high levels of antibodies against SEA were found in the CSF but not in the serum (Table 2 ) of three $(6 \%)$ paired samples. All three patients were male residents of areas endemic for schistosomiasis, and laboratory analysis identified increased levels of protein and eosinophils in their CSF. The immunofluorescence test result was negative for one sample and the fecal parasitologic examination results were negative for all three. After chemotherapy, all the patients showed improvement in their neurologic status. In cases where it was possible to perform the ELISA, they showed antibody levels in the CSF below those observed previously.

Immunoglobulin isotype characterization of the CSF samples (Figure 2), showed that IgM, IgG1, and IgG4 antibodies against SEA and SWAP had the highest median optical density values. However, nine patients with high CSF

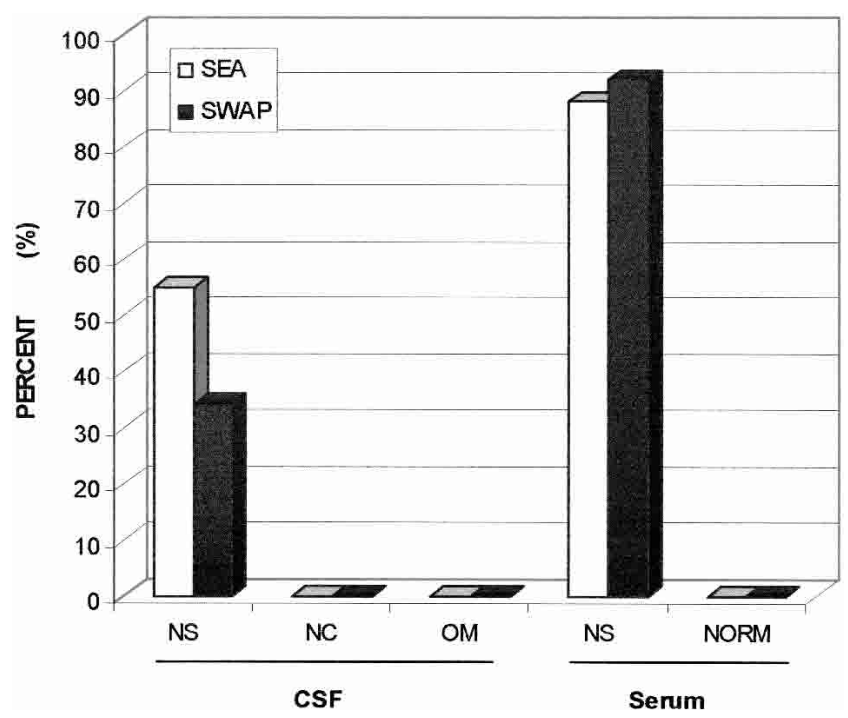

FIGURE 1. Percentage of samples from cerebrospinal fluid (CSF) and serum samples with high levels of IgG antibodies against Schistosoma mansoni soluble egg antigen (SEA) and soluble worm adult preparation (SWAP) obtained from patients with suspected neuroschistosomiasis (NS), neurocysticercosis (NC), and myelitis (OM). NORM $=$ normal, healthy controls. Antibodies were quantified by an enzyme-linked immunosorbent assay as described in the Materials and Methods. 
TABLE 2

ELISA results for SEA and SWAP antigens in 49 paired CSF and serum samples*

\begin{tabular}{lcc}
\hline \multicolumn{1}{c}{ ELISA results } & \multicolumn{2}{c}{ Antigens } \\
\hline \multicolumn{1}{c}{ CSF/serum } & SEA & SWAP \\
\hline Positive/positive & $28(57 \%)$ & $20(41 \%)$ \\
Positive/negative & $3(6 \%)$ & $0(0 \%)$ \\
Negative/positive & $15(31 \%)$ & $27(55 \%)$ \\
Negative/negative & $3(6 \%)$ & $2(4 \%)$ \\
Total & $49(100 \%)$ & $49(10 \%)$ \\
\hline *ELISA $=$ enzyme-linked immunosorbent assay: SEA = Schistosoma mansoni soluble
\end{tabular}

egg antigen; SWAP = soluble worm adult preparation; $\mathrm{CSF}=$ cerebrospinal fluid.

levels of IgG1 antibodies against SEA had negative serum samples. In the serum samples, IgM against SEA and SWAP had the highest optical density values.

\section{DISCUSSION}

The worldwide incidence and prevalence of spinal cord schistosomiasis is unknown. Few cases have been reported since the initial ones reported in the early 20th century. ${ }^{19}$ Neurologic complications caused by $S$. mansoni are uncommon, and reports of NS presenting as an intracerebral mass lesion are particularly rare. ${ }^{20}$ Although advances in clinical, laboratory, and radiologic technology have improved the ability to diagnose NS, the validity of serologic tests in diagnosing NS is still controversial. . $^{2,10,11,15-21}$
Although some investigators have used the ELISA to quantify antibodies in CSF, these investigations evaluated only reactivity to antibodies against SEA..$^{2,15,16}$ In our study, $55 \%$ of the CSF samples were reactive to SEA (26\% were reactive only to SEA and $29 \%$ to both SEA and SWAP), $34 \%$ were reactive to SWAP (5\% only to SWAP and $29 \%$ to both SEA and SWAP), and $40 \%$ were not reactive to any antigen. We increased the detectable amount of positive samples by $5 \%$ by including SWAP antigen in the ELISA. In this study, we identified three patients whose CSF samples were positive for total $\mathrm{IgG}$ but whose paired serum samples were negative. The fact that high levels of IgG1 were also identified in the CSF of nine cases that had negative serum results further supports the local production of $S$. mansoni-specific antibodies through oligoclonal synthesis in the CSF. This possibility has been suggested in previous investigations. ${ }^{22}$ In one of our patients, laminectomy and biopsy were performed and the histopathologic analysis revealed a granulomatous reaction around a $S$. mansoni egg in nerve tissue (Figure 3). To date, immunoglobulin isotype characterization has been performed only by immunohistochemistry on the choroids plexus, but there have been no immunoglobulin isotype profiles using $\mathrm{CSF}^{7}$ Our investigation shows, for the first time, that different immunoglobulin classes and isotypes could be detected by ELISA in the CSF of patients with suspected NS.

Antibodies against $S$. mansoni that are detectable in the CSF samples of patients with NS could reflect increased serum antibody titers. However, in this investigation, there were three patients who had total IgG antibodies exclusively
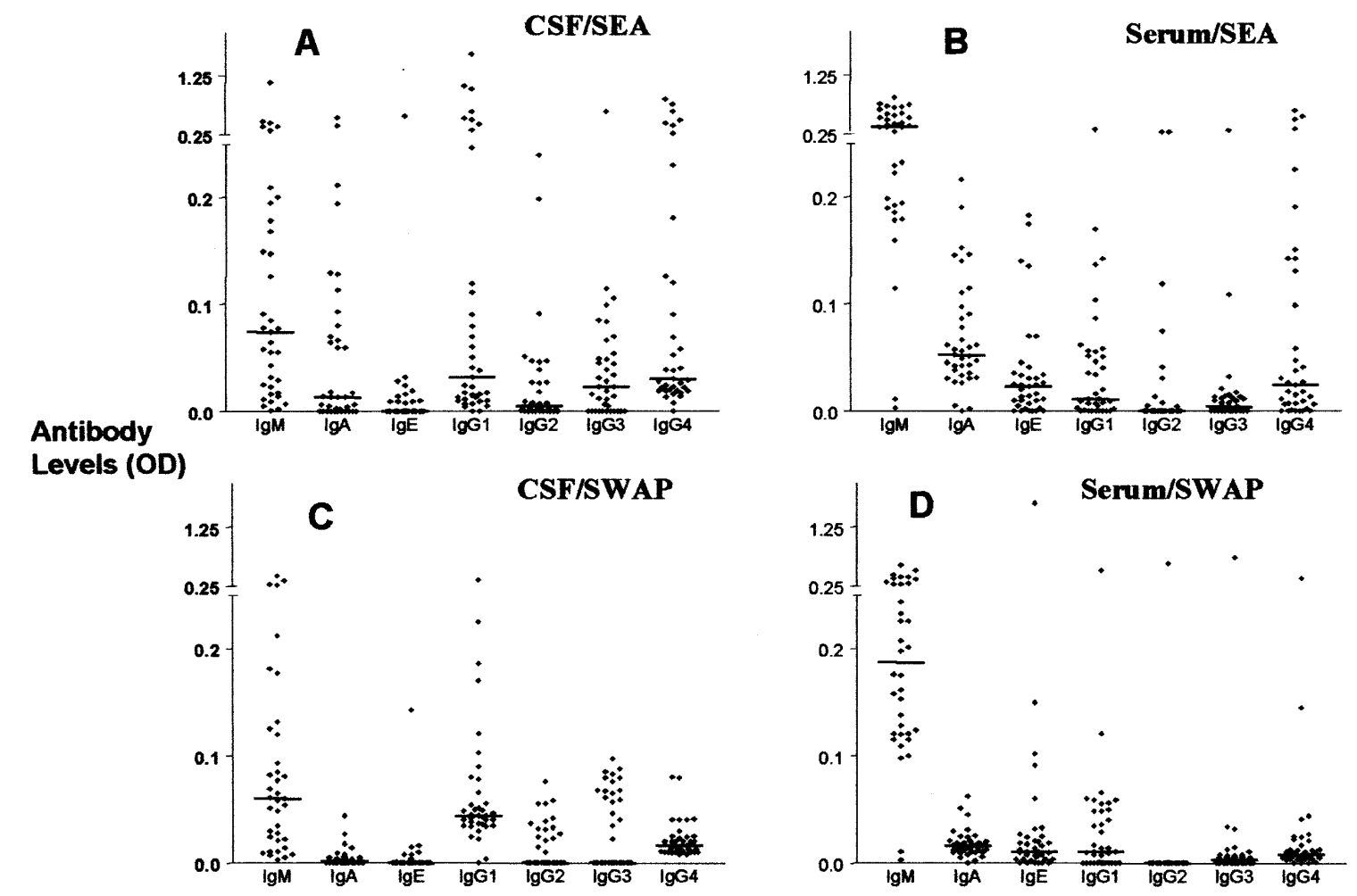

FIGURE 2. Isotypes of antibodies to Schistosoma mansoni in 37 cerebrospinal (CSF) and 34 serum samples of patients with neuroschistosomiasis. Each point corresponds to one individual. A. Immunoglobulin isotype levels against soluble egg antigen (SEA) in CSF samples; B, immunoglobulin isotype levels against SEA in serum samples; $\mathbf{C}$, immunoglobulin isotype levels against soluble worm adult preparation (SWAP) in CSF samples; D, immunoglobulin isotype levels against SWAP in serum samples. Antibodies were quantified by an enzyme-linked immunosorbent assay as described in the Materials and Methods. The horizontal lines show the ELISA cutoff values. OD = optical density. 


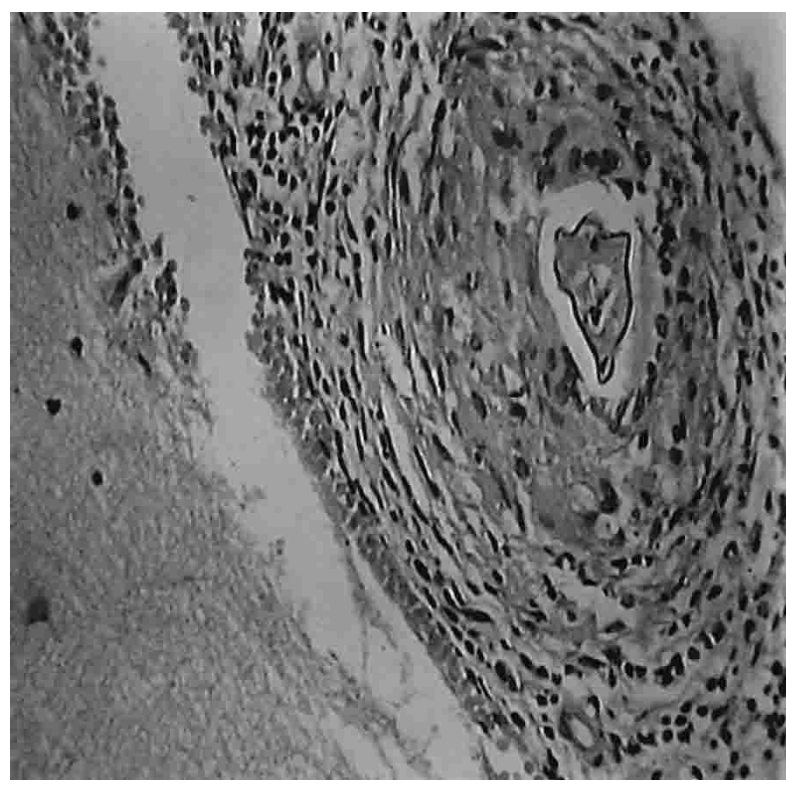

FIGURE 3. Laminectomy and biopsy sample from a patient with neuroschistosomiasis showing a granulomatosus reaction centered around a Schistosoma mansoni egg (magnification $\times 200$ ).

in their CSF samples and nine with the IgG1 subtype (Figure 2 ). Three patients with strong clinical epidemiologic evidence of NS had negative results on immunologic, immunofluorescence, and parasitologic examinations (Table 2). However, negative fecal examinations results could be due to the fact that only one sample was collected from each patient. The negative immunologic and immunofluorescence results in two cases may indicate antibody levels below our limit of detection.

Although we were able to detect antibodies to SEA and SWAP in $97.6 \%$ of the CSF samples by the ELISA, it was not possible to calculate the sensitivity and specificity of this test because, for ethical reasons, we were unable to obtain CSF from healthy donors and could not biopsy all patients to identify $S$. mansoni eggs in the CNS. Currently, the demonstration of eggs in a spinal biopsy specimen remains the only existing gold standard test, and is the only certain proof of NS. ${ }^{21} \mathrm{Al}-$ though we were unable to establish the sensitivity of the ELISA in this study, we have demonstrated that this assay is specific for $S$. mansoni infection, since there were no antibody cross-reactions in patients with neurocysticercosis or other neuropathies. Previous studies have shown that this assay can also be used to understand NS pathology. ${ }^{23}$ Our results indicate that $\mathrm{IgG1}$ is the most discriminating isotype marker for the diagnosis of NS. However, more investigations are necessary to confirm this hypothesis.

Received September 10, 2001. Accepted for publication September 25, 2002.

Acknowledgments: We thank the patients and the volunteers for their cooperation, the CPqGM-FIOCRUZ and the Federal University of Bahia for institutional support, and Craig Milroy and Ronald Blanton for help with the revision of this manuscript.

Financial support: This work was supported by CNPq (grants 350052/ 95-6 NV and 135100/95-0), Programa de Apoio ao Núcleo de Excelência (grant 261/96), and the National Institutes of Health (grant 5U01-AI-16305-17).
Authors' addresses: Isis F. Magalhães-Santos, Theomira M. A. Carmo, Isadora C. Siqueira, and Mitermayer G. Reis, Centro de Pesquisas Gonçalo Moniz-FIOCRUZ, Rua Waldemar Falcão 121 Brotas, Salvador, Bahia, Brazil, CEP-40295-001. Denise C. Lemaire, Instituto de Ciências da Saúde, Universidade Federal da Bahia, Salvador, Bahia, Brazil. Antonio S. Andrade-Filho, Departamento de Neurologia, Hospital Professor Edgar Santos, Universidade Federal da Bahia, Salvador, Bahia, Brazil. Aristides C. Queiroz, Departamento de Patologia, Hospital Professor Edgar Santos, Universidade Federal da Bahia, Salvador, Bahia, Brazil. Otávio M. Carvalho, Hospital Santo Amaro, Salvador, Bahia, Brazil. Débora M. Andrade, Michely F. Rego and Ana Paula T. Guedes, Faculdade de Medicina, Universidade Federal da Bahia, Salvador, Bahia, Brazil.

Reprint requests: Mitermayer G. Reis, Centro de Pesquisas Gonçalo Moniz-FIOCRUZ, Rua Waldemar Falcão 121 Brotas, Salvador, Bahia, Brazil CEP-40295-001, Telephone: 55-71-356-0129, Fax: 55-71356-2155, E-mail: miter@cpqgm.fiocruz.br

\section{REFERENCES}

1. World Health Organization, 1996. Schistosomiasis. Geneva: World Health Organization, 1-4.

2. Pammenter MD, Haribhai HC, Epstein SR, Roussow EJ, Bhigjee AI, Bill PLA, 1991. The value of immunological approaches to the diagnosis of schistosomal myelopathy. Am J Trop Med Hyg 44: 329-335.

3. Pollner JH, Schwartz A, Kobrine A, Parenti DM, 1994. Cerebral schistosomiasis caused by Schistosoma haematobium: case report. Clin Infect Dis 18: 354-357.

4. Pittella JEH, 1991. The relation between involvement of the central nervous system in schistosomiasis mansoni and the clinical forms of the parasitosis. A review. J Trop Med Hyg 94: 15-21.

5. Pittella JEH, Lana-Peixoto MA, 1981. Brain involvement in hepatosplenic schistosomiasis mansoni. Brain 104: 621.

6. Queiroz AC, 1984. Estudo do plexo coróide na esquistossomose mansônica: relação dos depósitos protéicos com a presença de glomerulonefrite associada. Acta Med Port 5: 219-221.

7. Pittella JEH, Bambirra EA, 1989. Histopathological and immunofluorescence study of the choroid plexus in hepatosplenic schistosomiasis mansoni. Am J Trop Med Hyg 41: 548-552.

8. Houpis J, Brattleboro MD, Vermont J, Oexmann MDJ, Martin MDG, Jacobi MD, 1984. Acute schistosomiasis with transverse myelitis in American students returning from Kenya. JAMA 252: 1116, 1119, and 1123.

9. Andrade NA, 1986. Neuroesquistossomose. Arq Neuropsiquiatr 44: 275-279.

10. Andrade-Filho AS, Queiroz AC, 1991. Meningomielorradiculite esquistossomótica: estudo clínico-laboratorial de três casos tratados. Arq Neuropsiquiatr 49: 80-82.

11. Pellegrino AJP, Oliveira SP, Porto CA, Santos LA, Menezes EE, Silva AP, Brito AL, Pinheiro SP, Pinheiro S, Dias AB, 1988. Meningomielorradiculite por Schistosoma mansoni. Protocolo de investigação e registro de 21 casos. Arq Neuropsiquiatr 46: 49-60.

12. Salum PNB, Machado LR, Spina-França A, 1981. Meningomielorradiculopatia na esquistossomose mansônica: avaliação clínica e do líquido cefalorraqueano em 16 casos. Arq Neuropsiquiatr 39: 289-295.

13. Canelas HM, Aidar O, Campos EP, 1951. Esquistossomose com lesões meningo-radículo-medulares. Arq Neuropsiquiatr 9: 4855.

14. Livramento JA, Machado LR, Silva LC, Spina-França A, 1985. Síndrome do líquido cefalorraqueano na neuroesquistossomose. Arq Neuropsiquiatr 43: 372-377.

15. Ferrari TCA, Moreira PRR, Ferrari MLA, 1993. Clinical and immunological study of schistosomal myeloradiculopathy. Ann Trop Med Parasitol 87: 295-297.

16. Ferrari TCA, Moreira PRR, Oliveira RC, Ferrari MLA, Gazzinelli G, Cunha AS, 1995. The value of an ELISA for the 
diagnosis of schistotomiasis mansoni myeloradiculopathy. Trans R Soc Trop Med Hyg 89: 496-500.

17. Katz N, Chaves A, Pellegrino J, 1972. A simple devise for quantitative determination of Schistosoma mansoni eggs in feces examined by the thick smear technique. Rev Inst Med Trop Sao Paulo 14: 397-400.

18. Harn DA, Mitsuyama M, David JR, 1984. Schistosoma mansoni: anti-egg monoclonal antibodies protect against cercarial challenge in vivo. J Exp Med 159: 1371-1387.

19. Silbergleit R, Silbergleit R, 1992. Schistosomal granuloma of the spinal cord: evaluation with MR imaging and intraoperative sonography. ARJ Am J Roentgenol158: 1351-1353.
20. Mackenzie IR, Guha A, 1998. Manson's schistosomiasis presenting as a brain tumor. Case report. J Neurosurg 89: 1052-1054.

21. Scrimgeour EM, Gajdusek DC, 1985. Involvement of the central nervous system in Schistosoma mansoni and Schistosoma haematobium infection. Brain 108: 1023-1038.

22. Ferrari TCA, Correa-Oliveira R, Xavier MAP, Gazzinelli G, Cunha AS, 1999. Estimation of the local synthesis of immunoglobulin $\mathrm{G}(\mathrm{IgG})$ in the central nervous system of patients with spinal cord schistosomiasis by the IgG index. Trans $R$ Soc Trop Med Hyg 93: 558-559.

23. Mott KE, Dixon H, 1982. Collaborative study on antigens for immunodiagnosis of schistosomiasis. Bull World Health Organ 60: 729-753. 